\title{
Chinese Growth: A Source of U.S. Export Opportunities
}

\author{
William Poole
}

This article was originally presented as a speech to the Fiscal Affairs and Government Operations Committee, Council of State Governments' Southern Legislative Conference (SLC), Louisville, Kentucky, July 31, 2006.

Federal Reserve Bank of St. Louis Review, November/December 2006, 88(6), pp. 471-83.

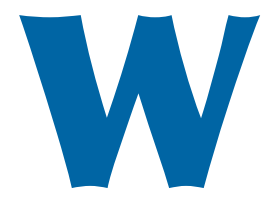

ith all the press reports about the enormous growth of China's exports to the United States, I start with a story running in the opposite direction. Kanawha Scales and Systems is a company located in Poca, West Virginia, which has a population of roughly 1,000. Chinese purchases of this company's coal-loading machines have grown to account for about one-third of the company's $\$ 50$ million in annual revenues. ${ }^{1}$

How many stories are there like the Kanawha Scales story? Well, I'll share another example. A recent report indicates that a group from Kentucky will be involved in the construction of a Thoroughbred racetrack in China, the first in mainland China. ${ }^{2}$ As part of this deal, 1,500 Kentucky Thoroughbreds will be sold and shipped to China and it is also possible that a number of Chinese will come to Kentucky to learn how to be trainers, exercise riders, jockeys, grooms, and hot walkers.

Are these isolated examples? Just how important to the United States are sales of U.S. goods and services to China?

\footnotetext{
1 See www.usatoday.com/money/world/ 2006-04-19-china-exports-usat_x.htm.

2 See http://charlotte.bizjournals.com/charlotte/stories/2006/03/20/ story6.html.
}

My purpose this morning is to convince you that the answer to this question is clear. Sales of U.S. goods and services to China are large, are growing, and are very important to the United States. In fact, as I'll detail shortly, firms in the 16 member states of the Southern Legislative Conference (SLC) are engaged in substantial exporting activity to China. I'll discuss major features of the economic relationship between the United States and China, but with special emphasis on U.S. exports to China because that critically important part of the relationship is not well understood.

Before proceeding, I want to emphasize that the views I express here are mine and do not necessarily reflect official positions of the Federal Reserve System. I thank my colleagues at the Federal Reserve Bank of St. Louis for their comments, particularly Cletus C. Coughlin, vice president and deputy director of research, who provided special assistance.

\section{TRADE PROSPECTS}

Increases in international trade depend on three key factors-income growth, reductions in trade barriers, and declines in transportation costs.

William Poole is the president of the Federal Reserve Bank of St. Louis. The author appreciates comments provided by colleagues at the Federal Reserve Bank of St. Louis. Cletus C. Coughlin, vice president and deputy director of research, provided special assistance. The views expressed do not necessarily reflect official positions of the Federal Reserve System.

(C) 2006, The Federal Reserve Bank of St. Louis. Articles may be reprinted, reproduced, published, distributed, displayed, and transmitted in their entirety if copyright notice, author name(s), and full citation are included. Abstracts, synopses, and other derivative works may be made only with prior written permission of the Federal Reserve Bank of St. Louis. 


\section{Figure 1}

\section{World Merchandise Export Growth and GDP Growth, 1950-2004}

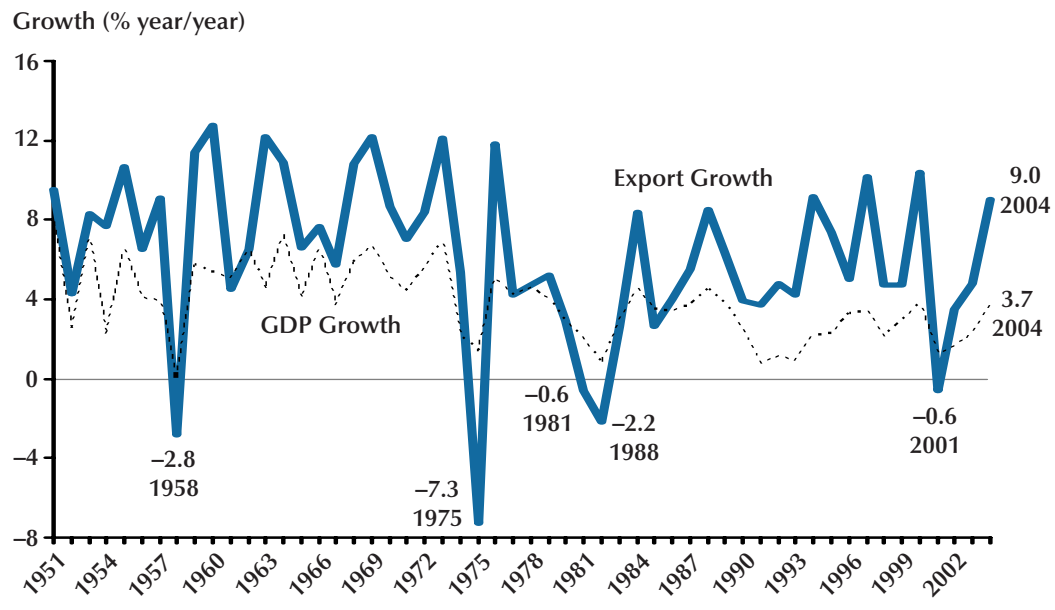

SOURCE: World Trade Organization, International Trade Statistics 2005.

Income growth has been the most important of these three factors stimulating increased trade worldwide, with reductions in trade barriers a distant second and declines in transportation costs an even more distant third. ${ }^{3}$ The direct implication of this research finding is that any discussion of trade flows should begin by examining income growth. In fact, almost without exception over the past 55 years, growth in world merchandise exports has exceeded growth in gross domestic product (GDP). ${ }^{4}$ (See Figure 1.)

It is reasonable, therefore, to anticipate a strong relationship between Chinese growth and U.S. exports, and that's exactly what we observe. The transformation of the Chinese economy has been accompanied by a huge increase in international trade and capital flows. U.S. exports to China have also been spurred by reductions in Chinese trade barriers, especially as part of China's

3 See Baier and Bergstrand (2001). Trade barriers and transportation costs are key components of trade costs, which are discussed in detail by Anderson and van Wincoop (2004).

4

Using annual data from the World Trade Organization's International Trade Statistics 2005, world merchandise export growth exceeded world GDP growth in all but eight years between 1950 and 2004. entry into the World Trade Organization in 2001. In addition to a substantial decline since 1982 in import tariffs, in 2005 China eliminated the licenses that were required for the importation of many goods. ${ }^{5}$

\section{CHINESE AND U.S. GROWTH}

China, with a population in excess of one billion, has maintained an astonishing rate of economic growth over the past 28 years. Beginning in 1978, China embarked on a series of policy changes that have led to an economy increasingly reliant on markets and price signals for allocating productive resources. ${ }^{6}$

As of July 2006, the Chinese population was 1.3 billion, which is more than four times as large as the U.S. population of 298 million. In terms of total production, measured in dollars at purchasing power parity, the Chinese economy is the

\footnotetext{
5 See "Building Explosion in China Pumps Up Exports from USA," a web article at www.usatoday.com/money/world/ 2006-04-19-china-exports-usat_x.htm in USA Today.

6 Prasad and Rajan (2006) estimate that between one-half and twothirds of the Chinese economy is currently market-based.
} 
Figure 2

China: The World's Second-Largest Single Economy in Terms of Purchasing Power Parity

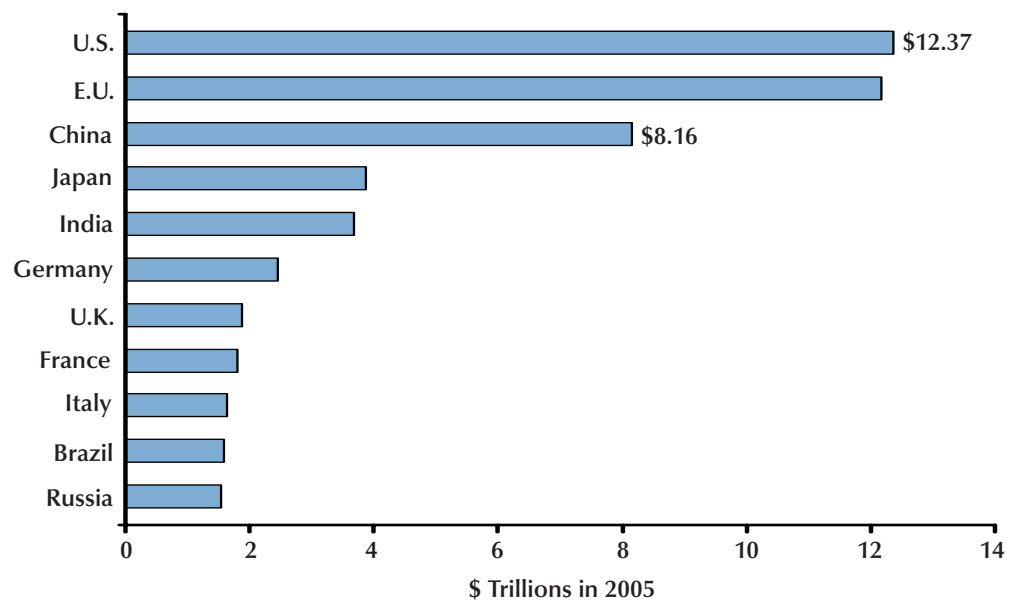

SOURCE: CIA World Factbook.

\section{Figure 3}

Leading Exporters and Importers in World Merchandise Trade, 2004

\begin{tabular}{|c|c|c|c|c|c|c|c|}
\hline Rank & Exporters & $\begin{array}{c}\text { Value } \\
\text { (\$ billions) } \\
\end{array}$ & $\begin{array}{c}\text { Share } \\
(\%)\end{array}$ & Rank & Importers & $\begin{array}{c}\text { Value } \\
\text { (\$ billions) } \\
\end{array}$ & $\begin{array}{c}\text { Share } \\
(\%)\end{array}$ \\
\hline 1 & Germany & 912.3 & 10.0 & 1 & United States & $1,525.5$ & 16.1 \\
\hline 2 & United States & 818.8 & 8.9 & 2 & Germany & 716.9 & 7.6 \\
\hline 3 & China & 593.3 & 6.5 & 3 & China & 561.2 & 5.9 \\
\hline 4 & Japan & 565.8 & 6.2 & 4 & France & 465.5 & 4.9 \\
\hline 5 & France & 448.7 & 4.9 & 5 & United Kingdom & 463.5 & 4.9 \\
\hline 6 & Netherlands & 358.2 & 3.9 & 6 & Japan & 454.5 & 4.8 \\
\hline 7 & Italy & 349.2 & 3.8 & 7 & Italy & 351.0 & 3.7 \\
\hline 8 & United Kingdom & 346.9 & 3.8 & 8 & Netherlands & 319.0 & 3.4 \\
\hline 9 & Canada & 316.5 & 3.5 & 9 & Belgium & 285.5 & 3.0 \\
\hline 10 & Belgium & 306.5 & 3.3 & 10 & Canada & 279.8 & 2.9 \\
\hline
\end{tabular}

SOURCE: World Trade Organization. 
Figure 4

\section{China's GDP per Capita}

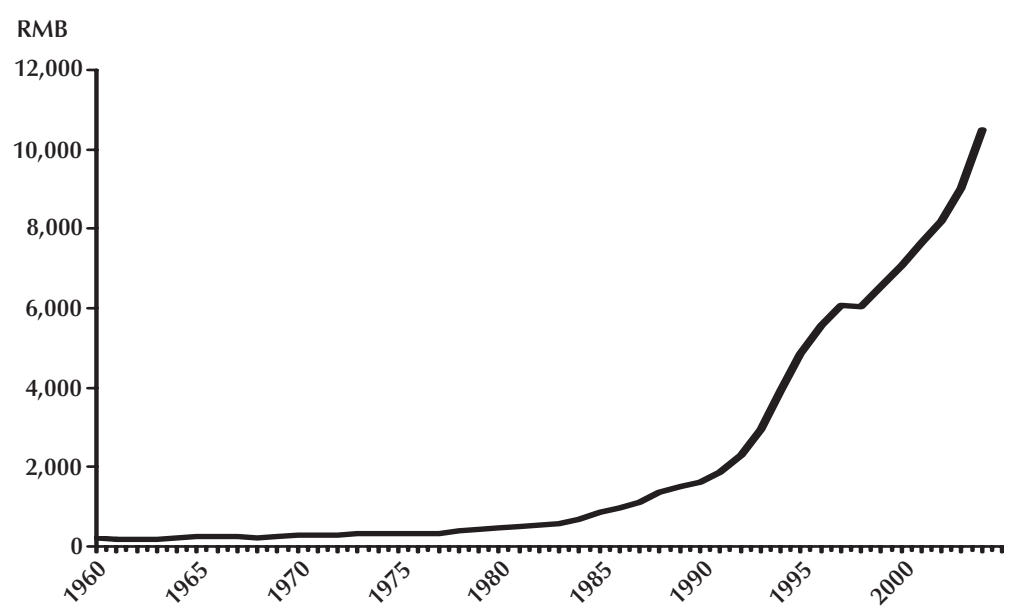

SOURCE: National Bureau of Statistics, China Statistical Yearbook 2004; National Bureau of Statistics Plan Report.

world's second-largest economy, trailing only the United States. In 2005 the Chinese GDP exceeded $\$ 8$ trillion, which was roughly two-thirds the U.S. GDP. (See Figure 2.) Not surprisingly, these two countries were two of the three leading exporting and importing countries in the world. ${ }^{7}$ (See Figure 3.)

The most vivid illustration of rapid Chinese growth can be seen by examining the Chinese economy on a per capita basis. Adjusted for inflation, China's per capita GDP in 2004 was 6.6 times its 1980 level. (See Figure 4.) Annual growth rates of real per capita GDP in excess of 5 percent have been the norm in recent years. (See Figure 5.) In the late 1970s, China's real GDP per capita was slightly less than 5 percent of the U.S. level. Today it exceeds 10 percent. (See Figure 6.) Thus, although the overall Chinese economy is large, China is still a country with a relatively low level of per capita income. To provide perspective,

7 For 2004, the leading countries in terms of total world exports were Germany with a 10.0 percent share, the United States with an 8.9 percent share, and China with a 6.5 percent share. In terms of imports, the leading countries were the United States with a 16.1 percent share, Germany with a 7.6 percent share, and China with a 5.9 percent share.
China's real per capita GDP today is about equal to U.S. per capita GDP in 1886.

\section{THEORY OF INTEGRATING A LARGE LABOR-ABUNDANT COUNTRY INTO THE WORLD ECONOMY}

Some basic economic theory will provide a foundation for viewing the integration of the Chinese economy into the world economy. The analysis applies not only to the integration of the Chinese economy but also to similar developments that are occurring simultaneously in India and the countries of the former Soviet Union. ${ }^{8}$

Economists view the integration of these economies into the global economy as a labor "shock." Their integration can be viewed as a very large increase in the world's effective labor supply. To facilitate my discussion, assume that the bulk of this increase in the labor supply in recent years has tended to be low-skilled. Employing this simplifying assumption, two consequences

8 This idea has been expressed by Wolf (2006). 
Figure 5

\section{Chinese and U.S. Growth Rates of Real GDP per Capita}

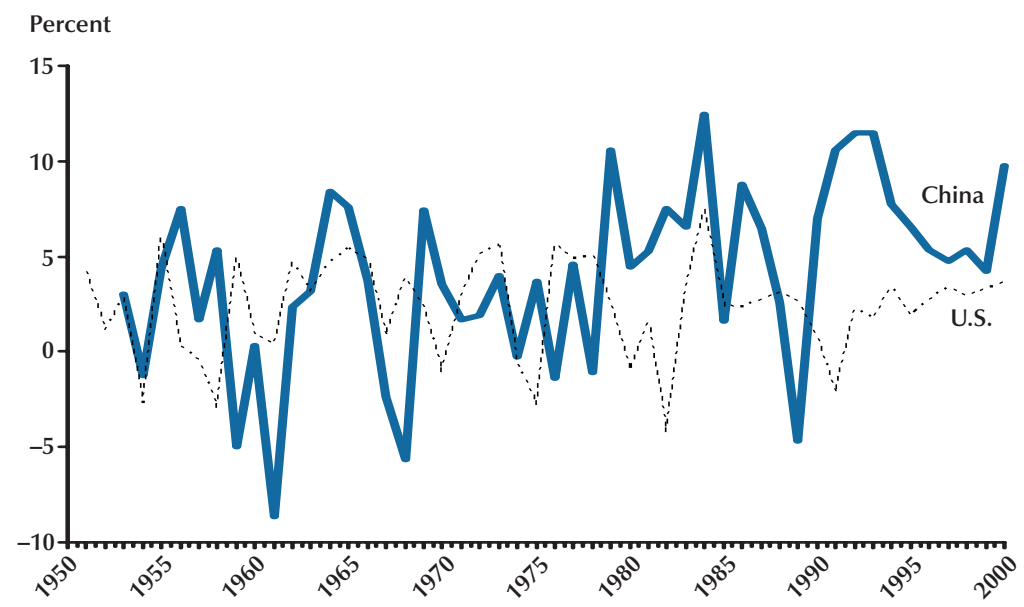

SOURCE: Penn World Tables (constant prices: chain series).

\section{Figure 6}

\section{China's Real GDP per Capita Relative to the U.S.}

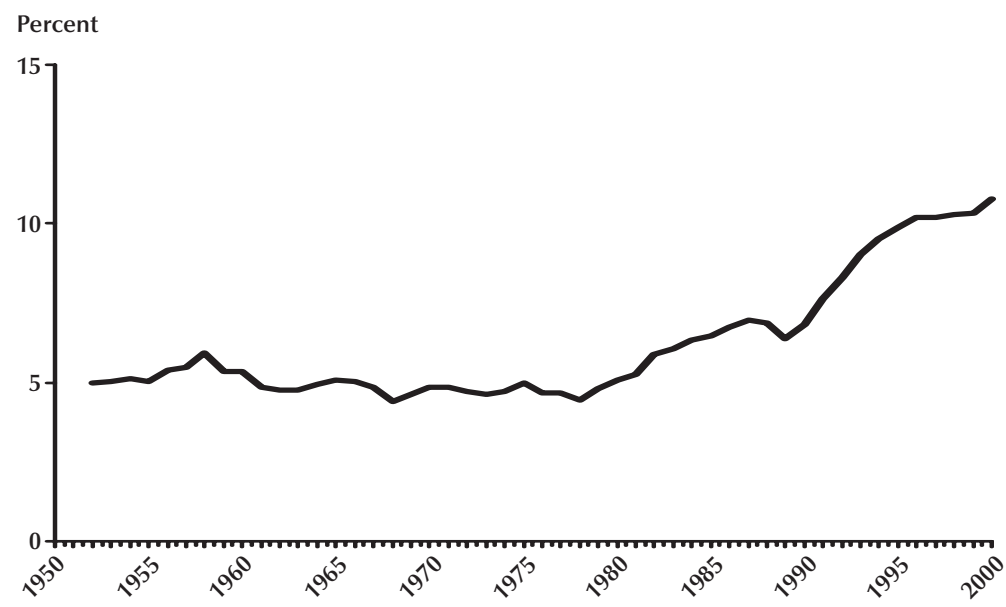

SOURCE: Penn World Tables (U.S. $=100$ in current prices).

are a direct result of the increased supply of lowskilled labor. One is that wages of low-skilled labor in high-income countries will tend to fall, or to increase more slowly, than before China's entry into the world trading system. Second, prices of those goods that require relatively large amounts of low-skilled labor should tend to decline relative to the prices of those goods that require relatively 
large amounts of high-skilled labor. For convenience of exposition, I'll refer to goods produced with low-skilled labor as "low-tech" goods and goods produced with high-skilled labor as "hightech" goods. Obviously, there is a continuum of goods from low to high tech, but the simplification will make it easy to understand the basic economic forces at work.

The first effect tends to depress income gains of low-skilled labor in high-income countries. Obviously, the share in total population of highskilled workers is greater in high-income countries than in low-income countries. Because of the large increase in low-skilled workers worldwide, lowskilled workers in the United States are likely to experience downward pressure on their real wages due to the increased competition associated with Chinese exports. ${ }^{9}$ The adverse income change generates demands for a government response to ameliorate the adverse market change.

The problem is real: Low-skilled workers in the United States have been adversely affected by imports of goods produced by low-skilled workers abroad. However, the nature of the government response is very important. Trade restrictions that hinder the importation of goods from China are unlikely to be a good solution because the United States would simply be forgoing the benefits of Chinese imports. Indeed, those lower-priced goods are important to lower-income, working families in the United States. The only appealing solution for the United States as a whole is to adopt policies that will increase the skill levels of affected workers, so that they can increase their compensation and employment prospects, which will allow them to adjust to the evolving economic environment.

Now consider the effect tending to reduce the prices of goods made with low-skilled labor. This relative price change, in which low-tech goods decline in price relative to high-tech goods, is associated with two other important price changes. The first involves a country's terms of trade, which is the (average) price of a country's exports relative to the (average) price of its imports.

9 In fact, declining real compensation for low-skilled workers has been an issue for many years in the United States.
In the case of China, the prices of the goods that China ships to the rest of the world should tend to decline relative to the prices of goods that it buys from the rest of the world.

Generally speaking, as the price of Chinese exports declines relative to the price of its imports, countries purchasing Chinese goods should become better off. In theory, the more dissimilar another country's production and consumption is to China's, the more likely the country is to benefit by China's integration into the world economy. Thus, a country such as the United States should tend to benefit from China's integration. Of course, the magnitude of the gains for the United States depends on the impact of Chinese exports on U.S. import prices. Recent research by staff economists at the Board of Governors of the Federal Reserve System found that Chinese exports have caused declines, albeit small, in U.S. import prices. ${ }^{10,11}$ The public-policy challenge is considerable, however, because gains for the United States as a whole are accompanied by downward pressure on wages of U.S. low-skilled workers, as already noted.

There is another change that reduces and possibly negates the net benefits for the United States. Coinciding with China's rapid growth has been substantial increases in China's imports of commodities such as oil. In fact, China has become the world's second largest consumer of oil. Chinese demand for oil has undoubtedly contributed to higher oil prices. Given the scale of U.S. oil imports, higher oil prices have certainly reduced the beneficial effects for the United States of recent developments in China. ${ }^{12}$

\footnotetext{
${ }^{10}$ See Kamin, Marazzi, and Schindler (2006).

${ }^{11}$ Rodrik (2006) argues that China's export bundle is more sophisticated than other countries with similar per capita incomes. While labor-intensive exports, such as toys, clothing, and electronics products that entail simple assembly operations, are important in China's export basket, Rodrik argues that foreign investment has played a major role in the evolution of Chinese exports. Foreign investors dominate Chinese exports. Their contribution of advanced technology, and the resulting transfer of technology, has resulted in Chinese exports that are relatively more sophisticated than those of comparably developed countries.

${ }^{12}$ Not surprisingly, oil is at the center of a contentious political issue. China's desire for increased oil supplies has led to relationships with a number of countries, such as Sudan and Uzbekistan, who many view as unsavory in terms of their records on human rights.
} 
Figure 7

\section{Chinese Exports and Imports as a Percent of GDP}

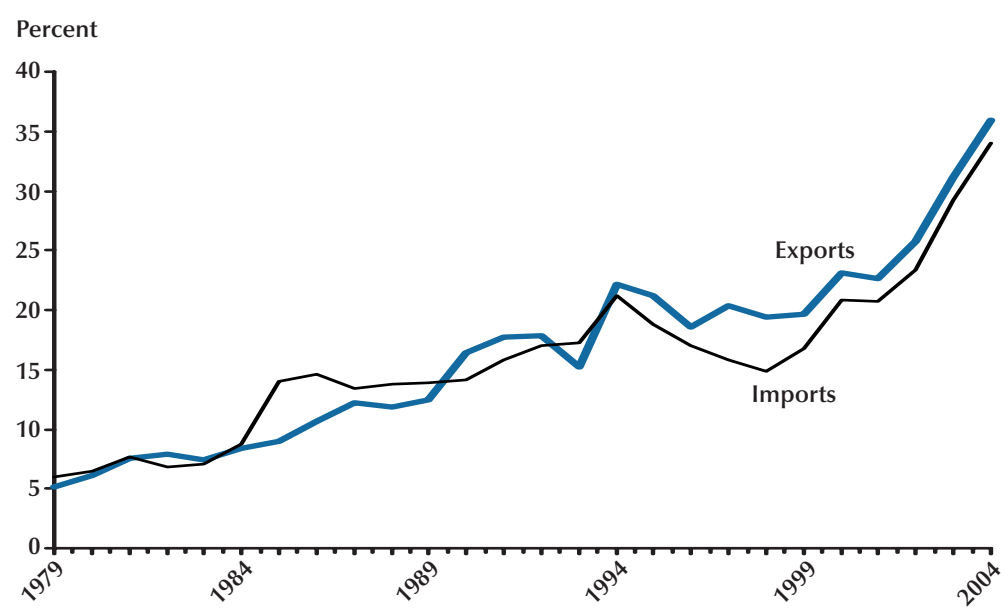

SOURCE: IMF, Direction of Trade Statistics, and official Chinese statistics.

\section{HOW CHINESE GROWTH AFFECTS TRADE}

The preceding discussion has focused on the relative-price impacts of China's integration into the world economy. Changes in relative prices, however, are not the only spur to changes in economic activity. China's economy has reached such a size that in recent years it has served as an engine of growth not only in Asia but also worldwide. Put simply, a wealthier China means rising Chinese demand for goods of all sorts, including high-tech goods that China does not produce.

One manifestation of this fact is that Chinese growth has resulted in large effects on overall trade flows. The integration of the Chinese economy into the world economy can be seen very clearly by examining how Chinese exports and imports have changed since the late 1970s. In 1979, Chinese exports as a share of Chinese GDP was 5 percent. Since then the share has risen to 36 percent. (See Figure 7.) The course of Chinese imports has taken a similar path, rising from roughly 6 percent of GDP in 1979 to 34 percent in 2005. These import and export shares may be compared with the shares for the United States:
Imports are 16 percent of U.S. GDP and exports are 10 percent.

As Chinese exports have grown faster than its imports, the Chinese trade balance has increased. A close look at China's trade balance reveals that from 1979 to the mid-1990s, the average yearly balance was roughly zero. (See Figure 8.) Since the mid-1990s, the balance has tended to rise, reaching a level of $\$ 102$ billion in 2005 , which is 4.4 percent of China's GDP.

\section{UNITED STATES-CHINA TRADE}

The increase of China's trade surplus since the mid-1990s coincides with a substantial increase in the United States-China bilateral trade balance. In 1995 the U.S. bilateral trade deficit with China was approximately $\$ 20$ billion. (See Figure 9.) Subsequently, this deficit has increased yearly, reaching $\$ 202$ billion for 2005, which was 28 percent of the overall U.S. trade deficit. (See Figure 10.) Surprisingly, in 1995, China's share of the overall U.S. trade deficit was actually larger, at 35 percent of the overall U.S. trade deficit.

Obviously, since 1995 the growth of U.S. imports from China has exceeded the growth of 


\section{Poole}

Figure 8

China's Trade Balance, 1979-2005

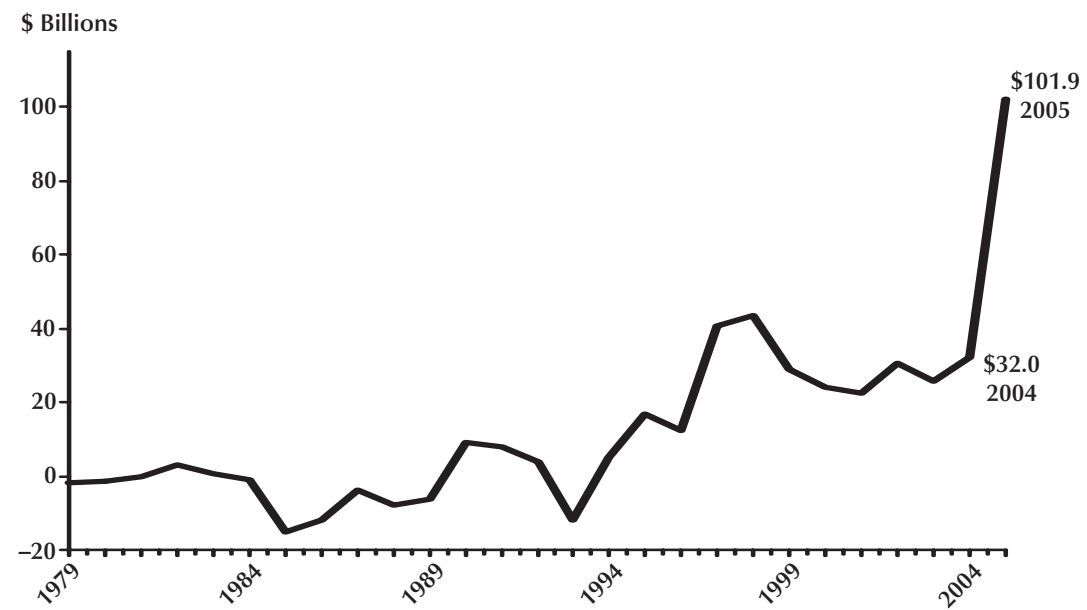

SOURCE: China Statistical Yearbook.

\section{Figure 9}

\section{U.S.-China Bilateral Trade Deficit and U.S. Trade Deficit}

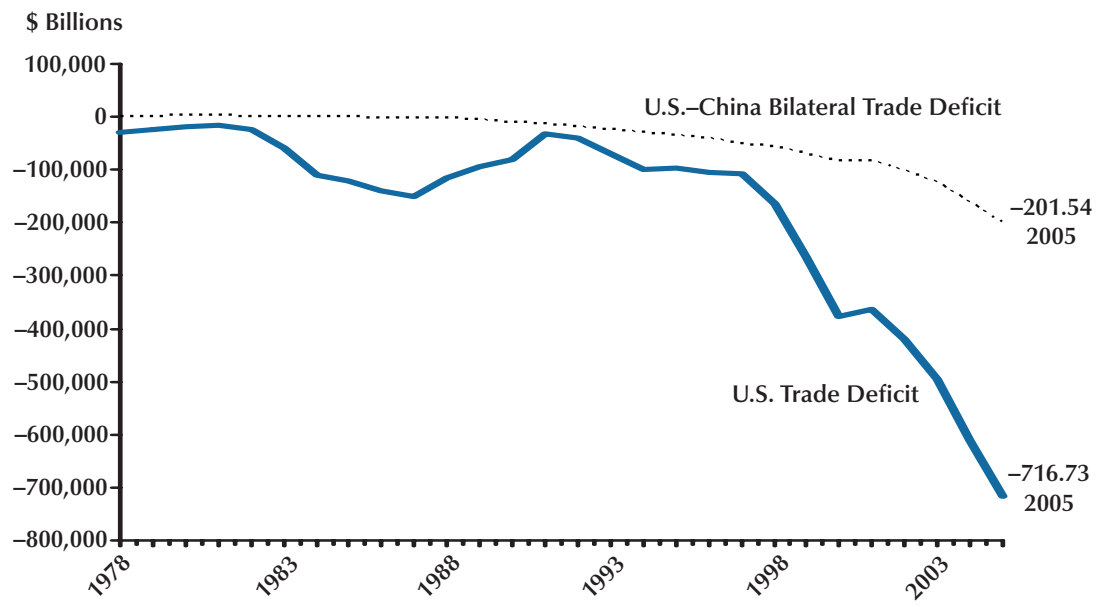

SOURCE: U.S. Census Bureau, Foreign Trade Statistics. 
Poole

Figure 10

China's Portion of the U.S. Trade Deficit

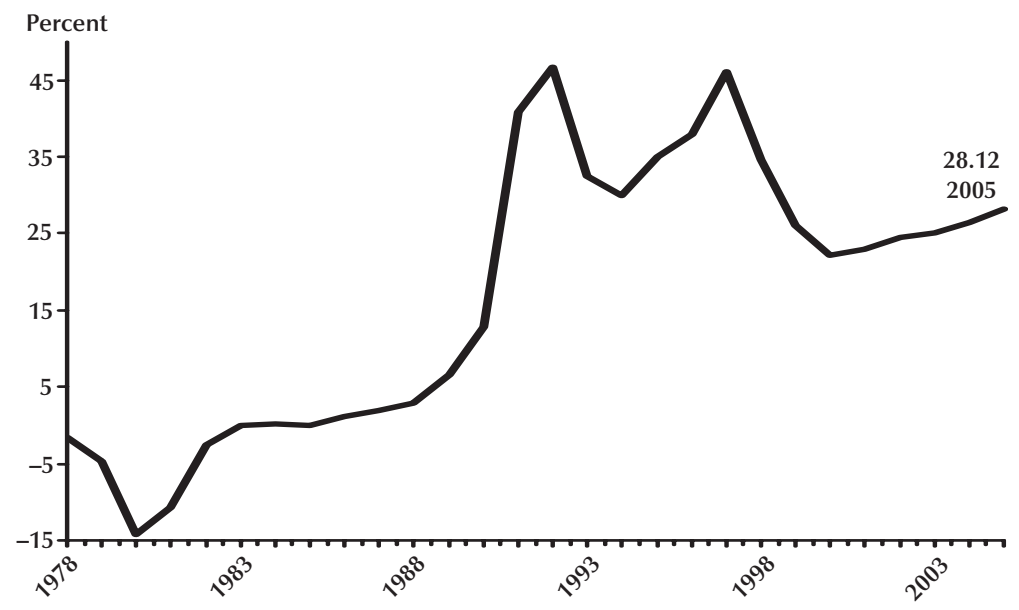

SOURCE: U.S. Census Bureau, Foreign Trade Statistics.

Figure 11

U.S. Exports to and Imports from China

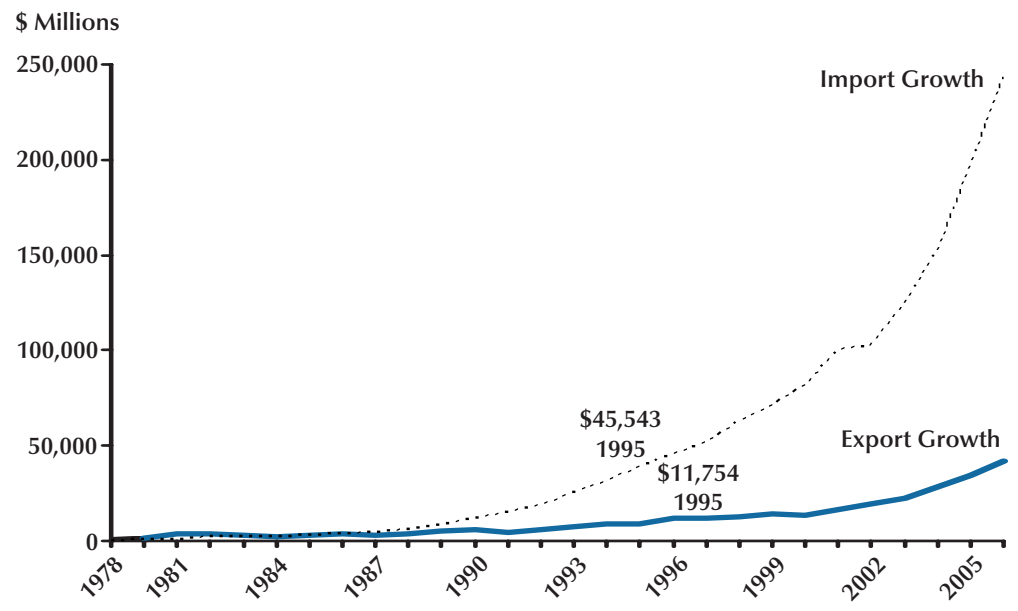

SOURCE: U.S. Census Bureau, Foreign Trade Statistics.

FEDERAL RESERVE BANK OF ST. LOUIS REVIEW

NOVEMBER/DECEMBER 2006

479 


\section{Table 1}

\section{Top 10 U.S. Exports to China-Ranked by 2005 Exports HS Industry Codes (\$ millions)}

\begin{tabular}{|c|c|c|c|}
\hline Code & Description & 2005 & $\begin{array}{l}\text { Share of U.S. } \\
\text { exports to China (\%) }\end{array}$ \\
\hline 85 & $\begin{array}{l}\text { Electrical machinery and equipment and parts thereof; } \\
\text { sound recorders and reproducers, television recorders } \\
\text { and reproducers, parts and accessories }\end{array}$ & 6,851 & 16.3 \\
\hline 84 & $\begin{array}{l}\text { Nuclear reactors, boilers, machinery and mechanical } \\
\text { appliances; parts thereof }\end{array}$ & 6,357 & 15.2 \\
\hline 88 & Aircraft, spacecraft, and parts thereof & 4,381 & 10.4 \\
\hline 90 & $\begin{array}{l}\text { Optical, photographic, cinematographic, measuring, } \\
\text { checking, precision, medical or surgical instruments } \\
\text { and apparatus; parts and accessories thereof }\end{array}$ & 2,397 & 5.7 \\
\hline 12 & $\begin{array}{l}\text { Oil seeds and oleaginous fruits; miscellaneous grains, seeds } \\
\text { and fruits, industrial or medicinal plants; straw and fodder }\end{array}$ & 2,289 & 5.5 \\
\hline 39 & Plastic and articles thereof & 2,259 & 5.4 \\
\hline 72 & Iron and steel & 1,555 & 3.7 \\
\hline 29 & Organic chemicals & 1,475 & 3.5 \\
\hline 52 & Cotton, including yarns and woven fabrics thereof & 1,411 & 3.4 \\
\hline 47 & $\begin{array}{l}\text { Pulp of wood or other fibrous cellulosic material; recovered } \\
\text { (waste and scrap) paper and paperboard }\end{array}$ & 992 & 2.4 \\
\hline
\end{tabular}

U.S. exports to China. Between 1995 and 2005, U.S. imports from China increased more than fivefold, while U.S. exports to China increased by a factor of 3.6. (See Figure 11.) But note this important fact: The growth in U.S. exports to China has been far greater than the growth of U.S. exports overall. Between 1995 and 2005, total U.S. exports increased by a factor of 1.6, which is less than half the rate of increase of U.S. exports to China. In light of the rapid Chinese growth, it is not surprising that U.S. exports to China rose rapidly. It is especially noteworthy that in 1995 China was the 13th leading export market for goods produced in the United States and in 2005 it was the 4th leading export market. Put simply, a wealthier China is a better market for U.S. goods and services, especially for high-tech and agricultural goods, which the United States produces in abundance.

Chinese purchases of U.S. goods took center

${ }^{13}$ See www.usatoday.com/money/world/ 2006-04-19-china-exports-usat_x.htm. stage during President Hu Jintao's visit to the United States last May. During the visit, President $\mathrm{Hu}$ agreed that China would buy $\$ 16.2$ billion worth of Boeing jets and various other goods, such as networking equipment, medical devices, and beef. A close look at the top 10 exporting industries to China in 2005 reveals that the industry code including aircraft was the third leading export industry and that the industry code including medical devices was the fourth leading export industry. (See Table 1.) The two leading industry codes were (i) electrical machinery and equipment and (ii) nuclear reactors, boilers, machinery, and mechanical appliances. Together, these industries accounted for 31.5 percent of U.S. exports to China.

Large multinational corporations play a major role in U.S. exports to China. However, according to the U.S. Commercial Service, since 1992 the number of small and midsize exporters has increased from 3,143 to 19,201, a gain of 511 percent. ${ }^{13}$ I opened my remarks today with an 
Table 2

SLC Top State Exports to China 2005

\begin{tabular}{|c|c|c|c|c|c|}
\hline State & $\begin{array}{l}\text { HS } \\
\text { commodity } \\
\text { code }\end{array}$ & Commodity description & $\begin{array}{l}\text { Top export } \\
2005 \text { value } \\
\text { (\$ millions) }\end{array}$ & $\begin{array}{l}\text { Total } 2005 \\
\text { exports value } \\
(\$ \text { millions })\end{array}$ & $\begin{array}{l}\text { Top export } \\
\text { as percent of } \\
\text { total exports }\end{array}$ \\
\hline TX & 85 & $\begin{array}{l}\text { Electric machinery, etc.; sound } \\
\text { equipment; TV equipment; parts }\end{array}$ & $1,164.30$ & $4,901.30$ & 23.76 \\
\hline LA & 12 & $\begin{array}{l}\text { Oil seeds, etc.; misc. grain, seed, fruit, } \\
\text { plant, etc. }\end{array}$ & $1,193.10$ & $1,896.00$ & 62.93 \\
\hline $\mathrm{TN}$ & 52 & $\begin{array}{l}\text { Cotton, including yarn and woven fabric } \\
\text { thereof }\end{array}$ & 760.40 & $1,411.40$ & 53.87 \\
\hline GA & 47 & $\begin{array}{l}\text { Pulp of wood, etc.; waste, etc. of paper } \\
\text { and paperboard }\end{array}$ & 139.30 & 978.70 & 14.23 \\
\hline NC & 84 & $\begin{array}{l}\text { Nuclear reactors, boilers, machinery, } \\
\text { etc.; parts }\end{array}$ & 163.90 & 774.40 & 21.17 \\
\hline VA & 81 & $\begin{array}{l}\text { Base metals nesoi; cermets; articles } \\
\text { thereof }\end{array}$ & 77.20 & 721.50 & 10.70 \\
\hline $\mathrm{FL}$ & 31 & Fertilizers & 255.10 & 690.40 & 36.95 \\
\hline SC & 85 & $\begin{array}{l}\text { Electric machinery, etc.; sound } \\
\text { equipment; TV equipment; parts }\end{array}$ & 88.30 & 622.20 & 14.18 \\
\hline $\mathrm{MO}$ & 84 & $\begin{array}{l}\text { Nuclear reactors, boilers, machinery, } \\
\text { etc.; parts }\end{array}$ & 84.60 & 499.50 & 16.94 \\
\hline $\mathrm{AL}$ & 39 & Plastics and articles thereof & 153.40 & 467.00 & 32.84 \\
\hline KY & 72 & Iron and steel & 103.60 & 400.90 & 25.85 \\
\hline MD & 84 & $\begin{array}{l}\text { Nuclear reactors, boilers, machinery, } \\
\text { etc.; parts }\end{array}$ & 55.40 & 284.30 & 19.49 \\
\hline MS & 87 & $\begin{array}{l}\text { Vehicles, except railway or tramway, } \\
\text { and parts, etc. }\end{array}$ & 22.00 & 164.80 & 13.38 \\
\hline AR & 28 & $\begin{array}{l}\text { Inorganic chemicals; precious and rare } \\
\text { earth metals and radioactive } \\
\text { compounds }\end{array}$ & 31.30 & 144.40 & 21.66 \\
\hline WV & 39 & Plastics and articles thereof & 53.90 & 135.40 & 39.82 \\
\hline OK & 84 & $\begin{array}{l}\text { Nuclear reactors, boilers, machinery, } \\
\text { etc.; parts }\end{array}$ & 46.70 & 94.30 & 49.55 \\
\hline
\end{tabular}

example of exports sales by Kanawha Scales and Systems. This same phenomenon of small firms selling to the Chinese market is found all over the United States. Consider Sharpe Mixers of Seattle. This firm makes specialized "absorbers mixers" that strip sulfur dioxide from power plant emissions. Chinese power plant construction is proceeding rapidly to meet large increases in power demand. Most of these power plants are coal-fired, and Sharpe has seen its Chinese business increase substantially since receiving its first order in 2004.
This additional business has led to 10 additional employees for a total of 30 .

\section{EXPORTS FROM SLC MEMBER STATES}

Let's look more closely at the total exports from the SLC states to China. It turns out that the two leading export sectors are the same as for the United States as a whole. Together, these industries-electrical machinery and equipment and 
nuclear reactors, boilers, machinery, and mechanical appliances-accounted for 25 percent of the SLC states' exports to China during 2005.

Looking at the SLC states individually, we see substantial differences in their exports to China. Electrical machinery and equipment is the leading export category for only two states-Texas and South Carolina-while nuclear reactors, boilers, machinery, and mechanical appliances is the leading export category for four states-North Carolina, Missouri, Maryland, and Oklahoma. (See Table 2.) For the remaining 10 states, various commodity codes appear: plastic products for Alabama and West Virginia, oil seeds for Louisiana, cotton for Tennessee, wood pulp for Georgia, base metals for Virginia, iron and steel products for Kentucky, fertilizers for Florida, vehicles and parts for Mississippi, and inorganic chemicals for Arkansas.

For these states, 2005 exports to China range from $\$ 4.9$ billion from Texas to $\$ 0.1$ billion from Oklahoma. One fact is that, for SLC states, exports to China relative to gross state product tend to be below the national average for all states together. Using figures for 2005, only 4 of the 16 SLC states had shares in excess of the national average of 0.36 percent. Those states were Louisiana (1.1), Tennessee (0.62), Texas (0.50), and South Carolina (0.45).

What is especially encouraging, however, is that firms in the SLC states have played a key role in the growth of exports to China. Comparing 2002 with 2005, total U.S. exports to China increased by a factor of 1.9. However, 13 of the 16 states represented at this meeting experienced export growth faster than the national average. The leader was Tennessee, whose exports increased by a factor of 4.2. Missouri was the second leading state, with exports to China increasing by a factor of 3.9. The only states lagging the national average were Mississippi (1.2), Florida (1.0), and West Virginia (0.9).

\section{CONCLUSION}

My message for you today can be summarized very succinctly: The growth of the Chinese econ- omy has provided and will almost certainly continue to provide U.S. firms with important export opportunities. This growing demand for U.S. goods and services provides not only more but also better-paying employment opportunities.

This simple message is easy to miss because the continuing integration of China into the world economy presents both political and economic challenges. It is still very easy to identify numerous factors that hinder the sales of goods and services to China by U.S. firms. ${ }^{14}$ Without question, Chinese infringement of intellectual property rights remains a problem that limits U.S. exports. In addition, government procurement policies, restrictions involving the wholesale and retail distribution of foreign products in China, and the lack of transparency of many regulations also limit U.S. exports.

As I look to the future, I continue to see much negotiation between the Chinese and U.S. governments as well as many adjustments to the changing economic and political environment by U.S. firms and consumers. Political pressures will continue to be felt by U.S. policymakers. Given the insights from economic theory as well as the lessons of economic history, my hope is that policymakers will resist the calls for isolationist responses. U.S. trade restrictions are highly unlikely to increase employment opportunities at home, but clearly would deprive American consumers of lower-cost goods from China. The best course of action is to continue to encourage China to protect intellectual property rights and to lower barriers on trade.

Taking advantage of the opportunities presented by Chinese growth-rather than simply attempting to negate the competitive pressuresis in the best interest of both countries. Opportunities to increase exports are in fact being seized by U.S. firms, many of which are located in the 16 states served by the Southern Legislative Conference. Recent export growth by nearly all of these states has exceeded the national average.

\footnotetext{
${ }^{14}$ E. Anthony Wayne, Assistant Secretary for Economic and Business Affairs in the U.S. Department of State, enumerated many of the contentious issues in a speech on May 25, 2005, at the Executive's Club of Chicago.
} 
In light of the continuing strong Chinese growth prospects, prospects for exports to China from the states represented here today are very bright.

I'll finish with a general comment. For over 70 years, since the Reciprocal Trade Agreements Act of 1934, the United States has led the way toward a more open international trading system, and I am hopeful that this historic process will continue. Both economic theory and economic history have provided ample reasons showing that changes in legislation and regulation that tilt toward economic isolation are unwise. Our future prosperity depends on continuing to build on past successes in extending open markets and enjoying the fruits of the productivity advances open markets promote.

\section{REFERENCES}

Anderson, James E. and van Wincoop, Eric. "Trade Costs." Journal of Economic Literature, September 2004, 42(3), pp. 691-751.

Baier, Scott L. and Bergstrand, Jeffrey H. "The Growth of World Trade: Tariffs, Transport Costs, and Income Similarity." Journal of International Economics, February 2001, 53(1), pp. 1-27.
Kamin, Steven B.; Marazzi, Mario and Schindler, John W. "The Impact of Chinese Exports on Global Import Prices." Review of International Economics, May 2006, 14(2), pp. 179-201.

Prasad, Eswar S. and Rajan, Raghuram G. "Modernizing China's Growth Paradigm." American Economic Review, May 2006, 96(2), pp. 331-36.

Rodrik, Dani. "What's So Special about China's Exports.” NBER Working Paper 11947, National Bureau of Economic Research, January 2006.

Wayne, E. Anthony. "China's Emergence as an Economic Superpower and Its Implications for U.S. Businesses." Remarks at The Executives' Club of Chicago, International Leadership Conference, Chicago, IL, May 25, 2005;

www.state.gov/e/eb/rls/rm/2005/46950.htm.

Wolf, Martin. "The Answer to Asia's Rise Is Not To Retreat from the World." Financial Times, March 15, 2006, p. 17. 
